\title{
Main Results of an Energy Audit in a Milk Processing Industry in Taquara, Southern Brazil
}

\author{
Rejane G. Gonçalves', Elton G. Rossini², José de Souza ${ }^{3}$, Alexandre Beluco ${ }^{4}$ \\ ${ }^{1}$ Universidade Federal de Pernambuco (UFPE), Recife, PE, Brazil \\ ${ }^{2}$ Universidade Estadual do Rio Grande do Sul (UERGS), Porto Alegre, RS, Brazil \\ ${ }^{3}$ Fundação Liberato Salzano Vieira da Cunha, Novo Hamburgo, RS, Brazil \\ ${ }^{4}$ Universidade Federal do Rio Grande do Sul (UFRGS), Porto Alegre, RS, Brazil \\ Email: albeluco@iph.ufrgs.br
}

How to cite this paper: Gonçalves, R.G., Rossini, E.G., de Souza, J. and Beluco, A. (2018) Main Results of an Energy Audit in a Milk Processing Industry in Taquara, Southern Brazil. Journal of Power and Energy Engineering, 6, 21-32.

https://doi.org/10.4236/jpee.2018.61003

Received: October 16, 2017

Accepted: January 27, 2018

Published: January 30, 2018

Copyright (c) 2018 by authors and Scientific Research Publishing Inc. This work is licensed under the Creative Commons Attribution International License (CC BY 4.0).

http://creativecommons.org/licenses/by/4.0/

\begin{abstract}
The industrial energy diagnosis presented in this work occurred in a milk product cooperative, from an analysis of energy consumption in the main milk industrialization and a diagnosis of energy end uses of lighting and cooling systems. Almost all stages of milk industrialization are used hot water and steam generated in the boilers. The largest electricity consumption in this sector is by electric motors followed by cooling needed to maintain the quality of milk products. Because energy costs represent a significant portion of the monthly cost of the company, an analysis of the energy costs of the past two years to check the consumption of active and reactive energy and power demand contracted is performed. This paper presents the main results of an energy audit in a milk processing industry in southern Brazil.
\end{abstract}

\section{Keywords}

Energy Audit, Energetic Efficiency, Milk Products Industry

\section{Introduction}

Energy is one of the basic pillars of mankind's evolution, being as important as water and today as well as information. At present, the economic growth of the vast majority of countries is directly proportional to the increase in energy consumption [1]. In this sense, a challenge in the modern world is to uncouple the growth of economic activities, in various fields, from energy consumption. Relief from this scenario can be achieved through better rationalization of energy use and greater application of energy audits and techniques to control energy con- 
sumption. Energy auditing can then be seen as a diagnosis of what can be done to make energy consumption more efficient and can also be seen as a measure of what has been done to improve energy efficiency.

In the industrial context, the word "efficiency" can be defined as "producing more with less energy" [2]. Therefore, the question is: how to evaluate the efficiency in the use of energy in a company in its plants and processes considering the quality and productivity of production lines. In the industrial sector, in less developed countries, energy efficiency has some barriers due to lack of information about the investment, cost performance of new technologies and return time. Generally, the search for better energy efficiency faces a series of obstacles, related to technological issues but also related to the human factor. A significant portion of low energy efficiency can be associated with poor consumer habits in all sectors of economic activity [3].

Improvements in energy use can be obtained by means of guidelines, actions and control of human resources, with better materials and costs, reducing the amount of energy required to get the same results or products [4]. Actions for energy conservation do not imply directly or necessarily in energy rationing, but the elimination of losses and waste by promoting its rational use without compromising productivity or the quality of products and services [5]. Ref. [6] presents an interesting tool encouraging the renovation of buildings with different lifetimes based on a study undertaken in Lombardy, Italy, aiming to obtain buildings more energy efficient. In this sense, some other works [7] [8] [9] [10] present in the literature discuss the energy audit of buildings for schools and other purposes and present very interesting results.

The work to implement measures allowing more efficient use of energy is arduous and the prior existence of public policies encouraging these actions can positively address this task, but lower costs for actions and a shorter time to return of investment always prevail as criteria for action feasibility [11]. This assertion must have different validities in different sectors of activity, and the study undertaken by Murphy reports that in residences in the Netherlands it is the perception of residents about energy conservation which prevails over expert opinions [12]. The application of rather malleable industrial practices focusing on more energy efficient results is discussed by Petek et al. [13] who also presents some interesting case studies.

A simple and straightforward way to obtain better efficiency in industrial processes is the process modeling and the subsequent optimization of production processes. Charan and Prasad [14] present a very interesting and detailed study to improve efficiency in a dairy industry based on a modeling of industrial processes. Another work [15] shows a study based on data collected in eight industrial buildings of automobile manufacturers in Italy and the assembly of a model to evaluate the impact of different actions which aimed at reducing energy consumption. On a different path, the work led by Thollander [16] characterizes energy consumption and identifies opportunities to raise energy efficiency 
in small and medium-sized industries in Belgium, Italy, Japan and Sweden.

Survey of data conducted in 2009 by the Brazilian National Confederation of Industries (CNI) enable an analysis of the potential for energy conservation as a function of the end use in various industrial sectors. The food and beverage industry has the seventh largest potential, in absolute terms, for the conservation of thermal energy and total energy consumption and the third largest potential, in absolute terms, for the conservation of electricity [17]. The food and beverage sector inserted in the dairy industry has great potential for energy savings in various uses. The use of electrical energy presents potential for energy savings in power, cooling, and lighting, which are the major consumers of electric energy in this industrial sector [18].

This paper discusses opportunities to use energy efficiency with energy diagnosis in a company of milk products that has two important points that should be considered. The first one is related to the administrative framework formed by employees of a public company that was privatized through the cooperative. The second point is that the profit does not belong to the company but to the State, therefore, any investment or technological change does not generate significant profitability for the cooperative.

The objective of this paper is to perform a diagnosis according to the reality of the company indicating possible changes. A data collection and analysis of energy consumption in each sector in the whole process of milk industrialization was done. An analysis on electricity bills was performed by checking the contracts with the supplier of energy. The energy consumption of active and reactive in accordance with the periods of the year and times of day and the demand of active power contracted and used was verified.

After that, the lighting systems and $\mathrm{HVAC}^{1}$ have been checked, the load installed and the main equipment used during processing. It was also evaluated the consumption of fuels for the generation of thermal energy in the boilers used in the process of pasteurization. After the survey data was determined, the potential for energy conservation for the final uses existing in the company through the identification of opportunities for deployment of measures that improve the use of energy.

\section{Energy Audit}

An energy audit is a sequence of inspection, survey and analysis of energy flows in a process or system to reduce the amount of energy input into the system without adversely affecting the quality of the energy outputs. An energy audit is the first step in identifying opportunities to reduce energy expenditure and carbon footprints. Rather than simply identifying sources of energy use, an energy audit seeks to prioritize energy-saving opportunities in terms of cost-effectiveness.

One of the strategies of efficiency is the energetic diagnosis which consists in the data collection about the supply and the uses of energy in the production ${ }^{1}$ Heating, Ventilation and Air Conditioning. 
process. For the evaluation of the situation which allows the objective definition of improvement actions to be conducted [19]. It is necessary to diagnose the energy reality to then establish priorities, implement the projects of improvement and reduction of losses and monitor their results, in a continuous process [20].

Figure 1 illustrates the steps of a program of rational use of energy. The four first steps shown in the right side of the energetic diagnosis meets the first two items at left, identifying and quantifying the energy flows throughout the production process for goods and services [20]. The energetic diagnosis does not deal in detail the economic aspects and discusses the energy consumption.

The data feeding the energy audit process, in this case objectively, will be obtained by consulting documents, inspecting equipment and evaluating industrial processes. The electricity consumption accounts provided by the local concessionaire will allow the elaboration of a time series of energy consumption. The equipment inspection aims to determine the consumption information of each equipment used in the industrial processes and in the support sectors of the company. The evaluation of the industrial processes aims an evaluation of possible stages of the industrial processes that are demanding a consumption of energy greater than expected.

\section{Checking the Processes}

The industry has a variety of environments where can be observed the energy consumption, lighting system; HVAC; electric motors and compressors; boilers.

The industry has three lighting environments: offices (administrative), external (at night) and the lighting of the industrial area including the laboratory. Considering the three environments, there are $17.088 \mathrm{~kW}$ of power installed in the lighting system. The average daily consumption of $27,574 \mathrm{kWh} 18 \%$ is used by the administrative sector, $35 \%$ used in environments of industrialization and $47 \%$ used for exterior lighting at night. Whereas twenty-two days in the administrative sector and thirty days in the industrial sector and external lighting,
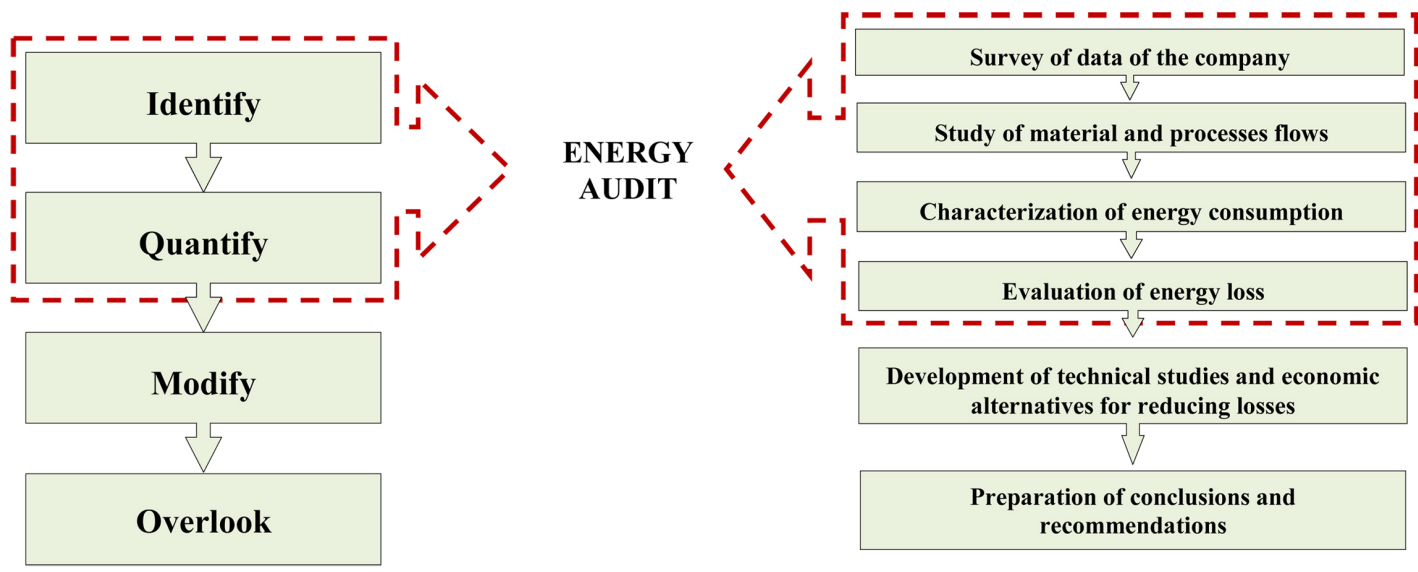

Figure 1. Stages of a program of rational use of energy. 
there are an average consumption of $8126.28 \mathrm{kWh} / \mathrm{m}$. Comparing this value with the sum of the monthly averages of active energy and outside edge, the sector of lighting accounts for approximately $4 \%$ of monthly consumption.

In the lighting system it is recommended to complement with fluorescent lamps on the laboratory benches to meet the minimum illuminance value indicated by the corresponding technical standard for this type of activity. In order to reduce lighting costs, it is recommended to reduce the power of the lamps in the administrative sectors, since in these places a value well above the minimum recommended by the corresponding technical standard has been verified and it is possible to have a good use of natural daylight. In outdoor lighting, it is recommended to shorten the time that the lamps remain lit at night by inserting light and motion sensors because the lamps used in this area represent $34 \%$ of the energy consumption in illumination.

The company has seven air conditioning equipments that represent a consumption of $27.26 \mathrm{kWh}$. Is there an average consumption of $6613.6 \mathrm{kWh} / \mathrm{m}$ which represents approximately $3 \%$ of monthly consumption of energy. It was verified that the refrigeration unit is regulated with temperature at $4^{\circ} \mathrm{C}$. The refrigeration unit is situated between the laboratory and the industrial sector of powdered milk without incidence of solar radiation this reduces considerably the heat load on the environment.

The total electrical load installed $(610 \mathrm{~kW})$ of electrical motors and compressors used in the main processes of industrialization of milk is higher than the total demand for electrical power employed by the company ( $550 \mathrm{~kW})$, however, the electric motors do not operate in all of its power and not all equipment operate simultaneously.

In the air conditioning sector, the main recommendation for cost reduction is the replacement of window-type air conditioners for split models that are more efficient and economical. It is recommended that in the acquisition of new appliances that verify the power according to the facilities and activities, therefore, it was verified equipment with power well above the necessary for thermal comfort in the administrative premises, caused unnecessary costs in air conditioning. Although no measurements of electrical quantities were made directly on the motors, the load factor and power factor analyzed from the electric power invoices allow concluding that some modifications of operation in the motors would bring significant reduction of energy consumption. Therefore, it remains as the main recommendation to increase the energy efficiency of the industry to perform such measurements and corrections.

The industry uses two fire tube boilers with each capacity for $6000 \mathrm{l} / \mathrm{h}$ of steam. Are burned daily about $90 \mathrm{~m}^{3}$ of wood. The wood used is, generally, eucalyptus or pine trees, which are, on average, lower calorific value of 3500 $\mathrm{kcal} / \mathrm{kg}$ and specific weight of $500 \mathrm{~kg} / \mathrm{m}^{3}$ [21]. Therefore, approximately 45,000 $\mathrm{kg}$ of wood is used per day, corresponding to $15.75 .107 \mathrm{kcal}$. Considering the efficiency of the boiler about $70 \%$, this is equivalent to $128.2 \mathrm{MWh}$ of thermal energy is used in the milk industrialization process. 
The tariff analysis showed that the company is correctly framed in the billing option and that the contracted power demand is in line with the needs of the industry. The analysis of the active and reactive energy consumption at the peak and off-peak times showed that it is not economically advantageous to use the generator at peak hours, as the company reduces the activities at that time.

Considering the process of milk industrialization, the largest source of energy used is of thermal origin, coming from the burning of wood in the boilers. Thus, reusing the water withdrawn in the process of manufacturing powdered milk to clean the machinery and treat it for use in the boilers represents a significant reduction of costs as well as shows the concern of the company with the environment.

For an industry of this size it is recommended the creation of an Internal Energy Conservation Commission (CICE) or some other group with specialized people whose task is to analyze the energy performance of the facility. The energy consumption data presented here may be used by the company for a complete program of rational energy use, including an economic feasibility analysis and time of investment return of the measures proposed here.

\section{Demand for Electrical Power and Energy Consumption}

The electric bills of the company from December 2011 to November 2013, including two complete cycles of wet and dry seasons, were evaluated. This allowed an energy analysis of the consumption of electric and power demand. In July 2012, the company reduced the contracted demand of $730 \mathrm{~kW}$ to $550 \mathrm{~kW}$ and, even so it can be verified that this two-year period the company has exceeded the value contracted only on two occasions. Evaluating the seven months that the company hires $730 \mathrm{~kW}$, the maximum demand was $524 \mathrm{~kW}$ off-peak times. After the reduction to maximum demand recorded, was $560 \mathrm{~kW}$ at peak times and $561 \mathrm{~kW}$ at off-peak times. Even so, it remained within the $10 \%$ allowed by legislation so that it will not be charged for demand for overtaking. Figure 2 shows the electrical power between December 2011 and November 2013.

Even the unitary value of $\mathrm{kW}$ cheaper for contracts for the larger demands the reduction of demand was important and represented a savings of $11.7 \%$, equivalent to approximately $\$ 1175.00$ per month. Figure 3 shows the active power consumption at peak times and off-peak times between December 2011 and November 2013. The average consumption in off-peak times was $186,635 \mathrm{kWh}$ and at peak times was $9891 \mathrm{kWh}$. These figures show that the industry seeks to reduce consumption during peak times. However, the cost of use of the generator at time of tip is not advantageous economically.

In the graph in Figure 3 there is not a directly proportional relationship between the consumption and the harvest period and season of the company. However, questioning employees about these differences, it was explained that the low value of consumption in the beginning of 2012 is due to the period of 


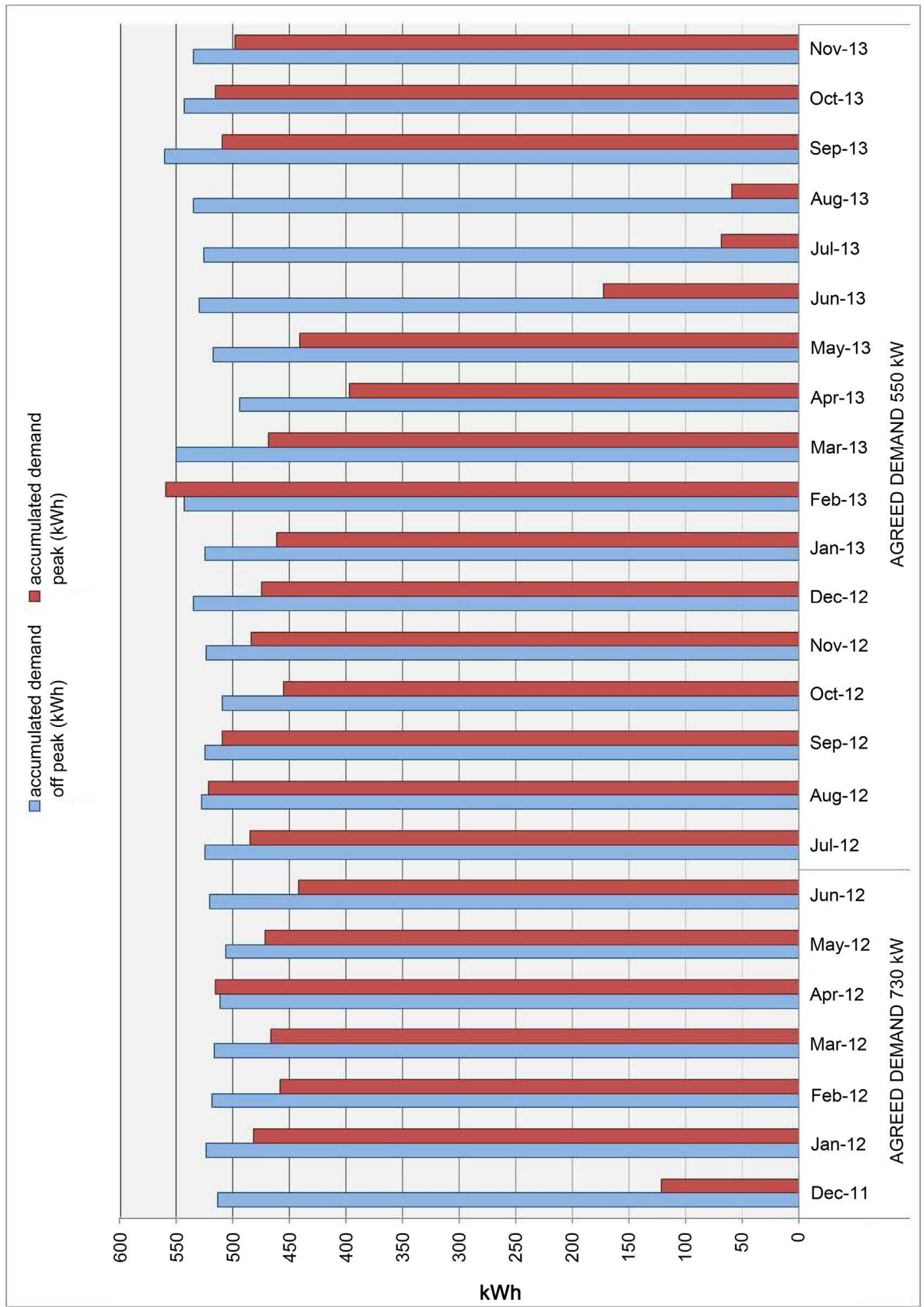

Figure 2. Graph with electric power demand between December 2011 and November 2013.

drought, which were in the region, which has done serious damage to agriculture and, consequently, the production of milk. The high consumption of July and August of 2012, in the offseason, is justified by the outsourcing of services. 


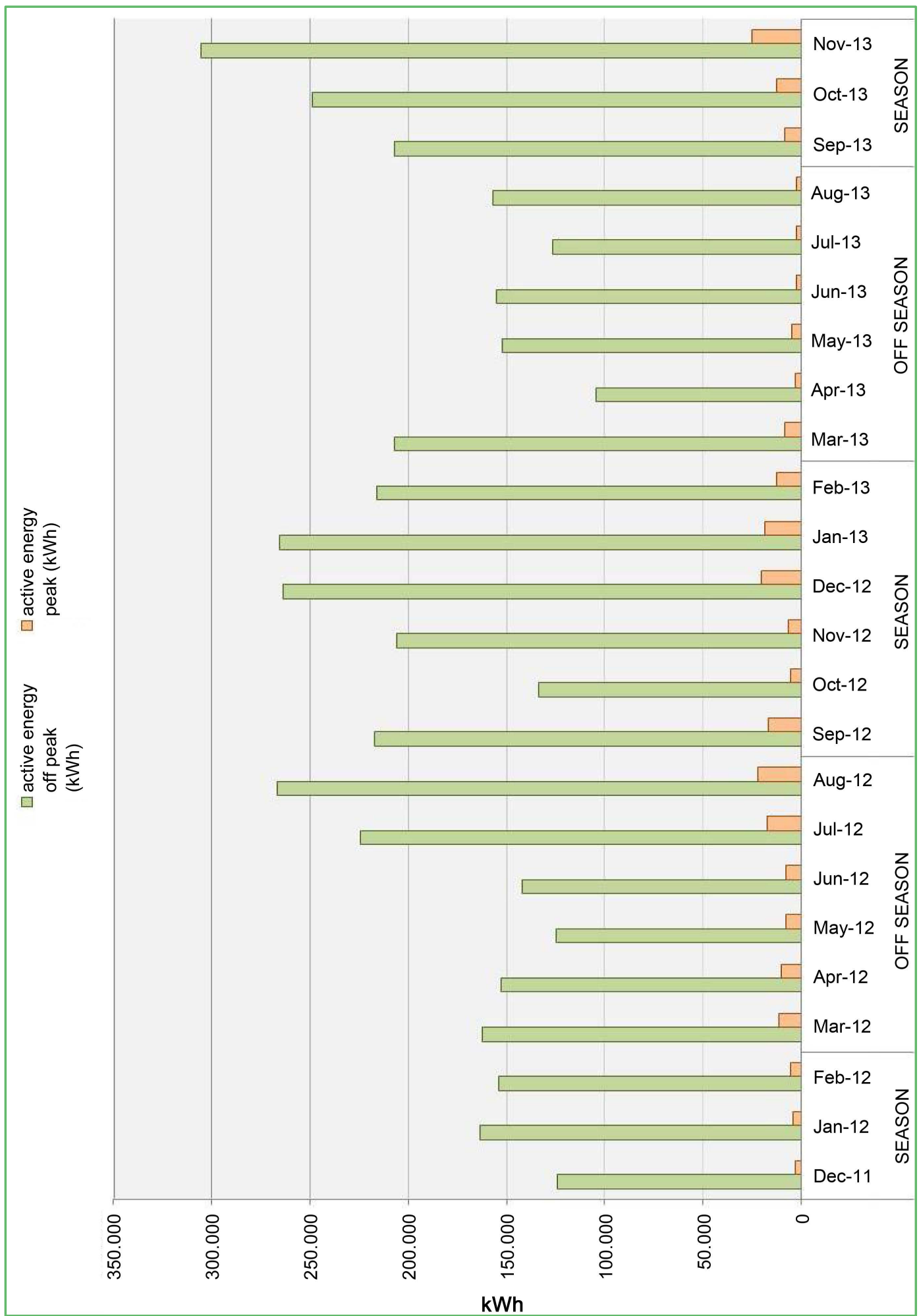

Figure 3. Graph with active energy consumption between December 2011 and November 2013.

Figure 4 shows how the load factor is unstable throughout the period under examination. The maximum value recorded at the off-peak times was 0.78 and the peak times is 0.72 , while the recommended by the legislation is not less than 
R. G. Gonçalves et al.

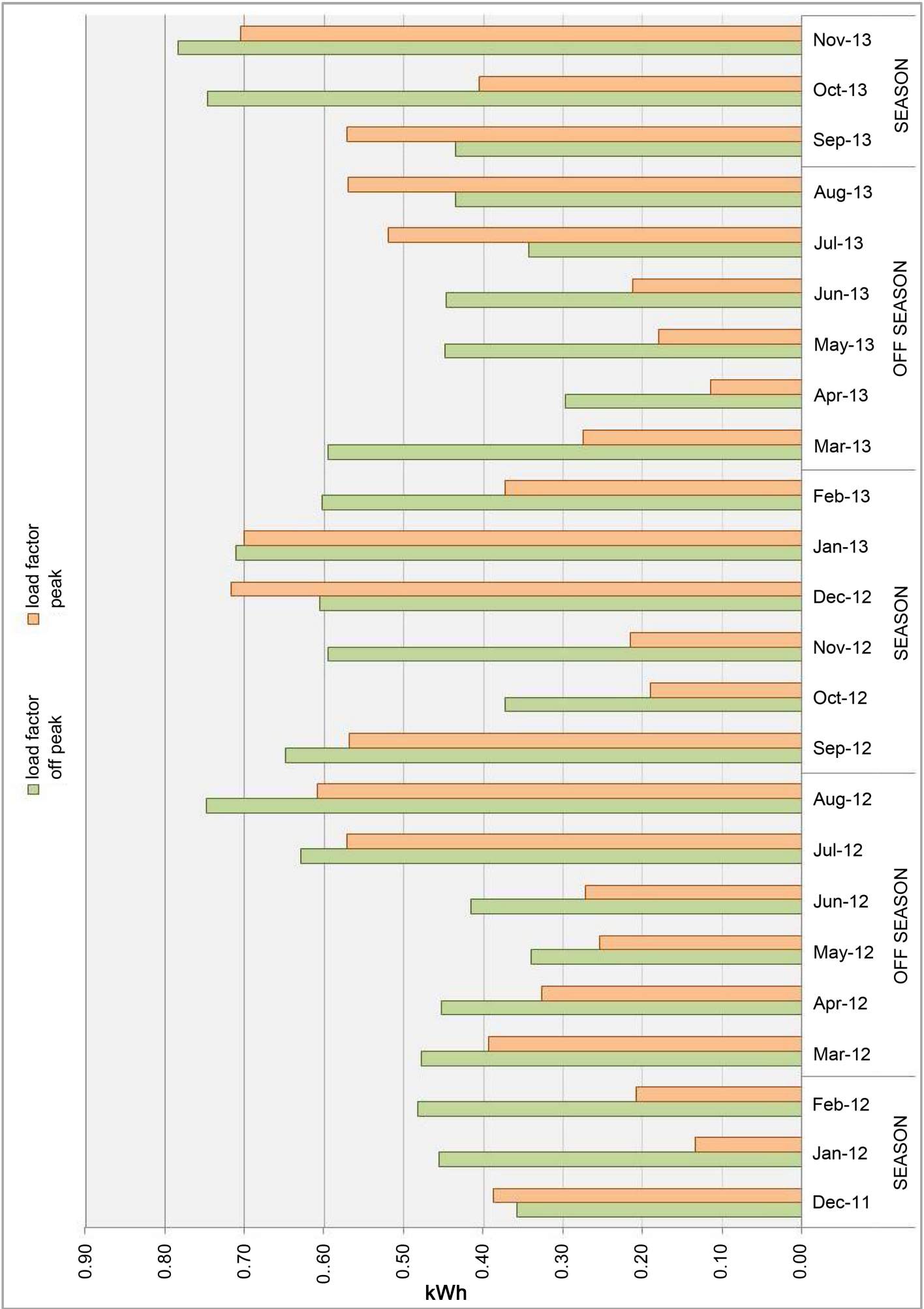

Figure 4. Graph with load factor between December 2011 and November 2013.

0.92. This indicates that there is a concentration of power in a short period of time, however, the average of 0.51 for the off-peak times and 0.39 for the peak times, respectively, are within the typical value for this industrial activity. 


\section{Conclusions}

This paper presented the main results of the application of a basic energy audit methodology to a dairy industry. From the visits carried out to accompany the industrialization of milk, the transformation of electric and thermal energy during the production process was studied, as well as a diagnosis of the end uses in the company, such as lighting, air conditioning and power. In general, the analysis of the data allows concluding that the company makes good use of electric energy and that has been developing actions in order to increase energy efficiency.

Based on requests made and the analysis performed in relation to the energy consumption of the main processes of industrialization of milk, a diagnosis in accordance with the energy consumption of the company in each sector was performed. There were components of the industry where the energy consumption was greater than that required for the realization which each stage of the production process of milk from this point was proposed new suggestions to be avoided this consumption in excess.

On the lighting sector, the tubular fluorescent lamps were replaced by fluorescent TL5 HO, reducing energy consumption. In the sector, air conditioning was recommended to be installed an automatic switch so the lamps were turned off automatically, so when they had people on site that would be avoided. The sector of electric motors and compressors can realize the total load installed is greater than the total demand of power employed by the company, but taking into account that the facilities are not used simultaneously. There are major concerns. The boilers had a considerable increase in the use of heat, when it was replaced coal for firewood, which was usually eucalyptus or pine wood. Therefore, from all aspects raised in the house process of industrialization, one can conclude that the company may still reduce more excessive consumption of energy.

\section{Acknowledgements}

This work was developed as a part of research activities on energy engineering at the Universidade Estadual do Rio Grande do Sul (UERGS). The authors acknowledge the support received by the institution. The fourth author acknowledges the financial support received from $\mathrm{CNPq}$ for his research work (proc. $\mathrm{n}$. 309021/2014-6).

\section{References}

[1] Sørensen, B. (2017) Renewable Energy, Physics, Engineering, Environmental Impacts, Economics and Planning. Academic Press, London, 1056 p.

[2] BRASIL. Confederação Nacional da Indústria. Eficiência energética na indústria. Brasília-DF, CNI, ELETROBRÁS-PROCEL Indústria, 2009. http://www.energia2015.eco-financas.org.br/assets/Relatorio_Procel_Industria.pdf

[3] Smith, C.B. (1981) Energy Management Principles: Applications, Benefits, Savings. Pergamon Press, New York, 516 p. 
[4] Domanski, E.L.V. (2008) Desenvolvimento de um diagnóstico energético para avaliar o uso de energia elétrica no setor industrial. Monografia (Graduação) do curso de Engenharia de Energia da Universidade Estadual do Rio Grande do Sul. Novo Hamburgo, Brazil, 36 p.

[5] Lawder, J.H. (2012) Análise energética e econômica em uma agroindústria de laticínios. Dissertação de Mestrado para o Programa de Pós-Graduação em Energia na Agricultura, Universidade Estadual do Oeste do Paraná, Cascavel, Brazil, 93 p.

[6] Bonacina, C.F., Masera, G. and Pavan, A. (2015) Investment Grade Energy Audit: A Financial Tool for the Cost Effective Renovation of Residential Buildings. Energy Procedia, 70, 709-718. https://doi.org/10.1016/j.egypro.2015.02.180

[7] Alajmi, A. (2012) Energy Audit of an Educational Building in a Hot Summer Climate. Energy and Buildings, 47, 122-130.

https://doi.org/10.1016/j.enbuild.2011.11.033

[8] Ascione, F., Bianco, N., De Mais, R.F., Rossi, F. and Vanoli, G.P. (2015) Energy Retrofit of an Educational Building in the Ancient Center of Benevento, Italy; Feasibility Study of Energy Savings and Respect of the Historical Value. Energy Buildings, 95, 172-183. https://doi.org/10.1016/j.egypro.2017.09.359

[9] Hassouneh, K., Al-Salaymeh, A. and Qoussous, J. (2014) Energy Audit, an Approach to Apply the Concept of Green Building for a Building in Jordan. Sustainable Cities and Society, 14, 456-462. https://doi.org/10.1016/j.scs.2014.08.010

[10] Lara, R.A., Pernigotto, G., Cappelletti, F., Romagnoni, P. and Gasparella, A. (2015) Energy Audit of Schools by Cluster Analysis. Energy and Buildings, 95, 160-171. https://doi.org/10.1016/j.enbuild.2015.03.036

[11] Annunziata, E., Rizzi, F. and Frey, M. (2014) Enhancing Energy Efficiency in Public Buildings: The Role of Local Energy Audit Programmes. Energy Policy, 69, 364-373. https://doi.org/10.1016/j.enpol.2014.02.027

[12] Murphy, L. (2014) The Influence of Energy Audits on the Energy Efficiency Investments of Private Owner Occupied Households in the Netherlands. Energy Policy, 65, 398-407. https://doi.org/10.1016/j.enpol.2013.10.016

[13] Petek, J., Glavic, P. and Kostevsek, A. (2016) Comprehensive Approach to Increase Energy Efficiency Based on Versatile Industrial Practices. Journal of Cleaner Production, 112, 2813-2821. https://doi.org/10.1016/j.jclepro.2015.10.046

[14] Charan, R. and Prasad, R. (1993) Energy Conservation in Milk Spray Drying Plant. Journal of Food Engineering, 18, 247-258. https://doi.org/10.1016/0260-8774(93)90089-3

[15] Dongellini, M., Marinosci, C. and Morini, G.L. (2014) Energy Audit of an Industrial Site: A Case Study. Energy Procedia, 45, 424-433. https://doi.org/10.1016/j.egypro.2014.01.046

[16] Thollander, P., Paramonova, S., Comelis, E., Kimura, O., Trianni, A., Karlsson, M., Cagno, E., Morales, I. and Navarro, J.P.J. (2015) International Study on Energy End-Use Data among Industrial Small and Medium Sized Enterprises and Energy End Use Efficiency Improvement Opportunities. Journal of Cleaner Production, 104, 282-296. https://doi.org/10.1016/j.jclepro.2015.04.073

[17] Bajay, S.V., Bordoni, O.F.J.G. and Gorla, F.D. (2009) Os segmentos industriais energo-intensivos de maiores potenciais técnicos de conservação de energia no Brasil. Revista Brasileira de Energia, 15, 89-107.

[18] Kawano, B.R. (2013) Otimização na Indústria de Laticínios: Oportunidades de eficiência energética e econômica. Dissertação de Mestrado da Faculdade de Engenharia Mecânica da Universidade Estadual de Campinas. UNICAMP, Brazil, 
$120 \mathrm{p}$.

[19] Guilliod, S.M. and Cordeiro, M.L.R. (2010) Manual do Pré-Diagnóstico Energético-Autodiagnóstico na Área de Prédios Públicos. Procel, Rio de Janeiro, Brazil.

[20] Nogueira, L.A.H. (2006) Auditoria energética. In: Marques, M.C.S., Haddad, J., Martins, A.R.S., Eds., Conservação de energia: Eficiência energética de equipamentos e instalações, 3rd Edition, Itajubá-MG, FUPAI.

[21] Pereira, J.C.D., Sturion, J.A., Higa, A.R., Higa, R.C.V. and Shimizu, J.Y. (2000) Características da madeira de algumas espécies de eucalipto plantadas no Brasil. Colombo-PR, Embrapa Florestas. 